\title{
SILVA Y SOLEDAD (ANÁLISIS COMPARATIVO DE ALGUNOS PASAJES DE GINOVÉS Y GÓNGORA)
}

Antonio Pérez Lasheras

El trabajo que presentamos consiste, básicamente, en una lectura detenida del poema del Licenciado aragonés Matías Ginovés, "Selva al verano, en canción informe", en el que hemos resaltado algunos pasajes que han sido comparados con otros semejantes de la Soledad primera gongorina. Hemos renunciado a ahondar en aquellos versos que la crítica había relacionado con otras composiciones del poeta cordobés, de los que hablaremos sólo de pasada.

No ha sido nuestro propósito incidir en ningún tema en especial, pero, a posteriori, nos hemos encontrado con que los fragmentos seleccionados para el cotejo tenían puntos claros de coincidencia, ya que todos ellos hacían mención, directa o indirectamente, a la metáfora, antigua, manida ya, pero siempre novedosa y verdecida, del mundo como página del gran libro de la Naturaleza. Ríos, pájaros, abejas, flores, estrellas, etc., todo constituye -incluso el propio hombre - una página de ese gran Libro, del que es preciso leer para llegar a entender las "mil verdades claras" de las que nos habla Ginovés.

La Selva al verano ofrece muchas semejanzas con la obra gongorina, algunas de las cuales han sido ya señaladas por los pocos críticos que se han acercado al poema de Ginovés. Aurora Egido señala que sigue "la línea de las Soledades de Góngora” (Egido [1978], pág. 33) y nos recuerda su vinculación con las silvas: 
No hay lucha, sino equivalencias, como ocurre en casi todas las "silvas". $Y$ desde su cronologia abrileña (la Soledad I: "era del año la estación florida"), a su lenguaje, Góngora arropa su visión del paisaje. Diria más, lo contempla a través suyo, como éste lo vio por tantos ojos de Camoes, por ejemplo: "Era no tempo alegre, quando estrava, ..." (Egido [1979] pág. 219).

Una de las coincidencias del poema de Ginovés con un fragmento de la primera versión del Polifemo gongorino llevó a José Manuel Blecua a fechar el poema entre 1613 y 1628 . Se trata de un fragmento que Ginovés corrigió tras la modificación que Góngora introdujo en el que le había servido como modelo :

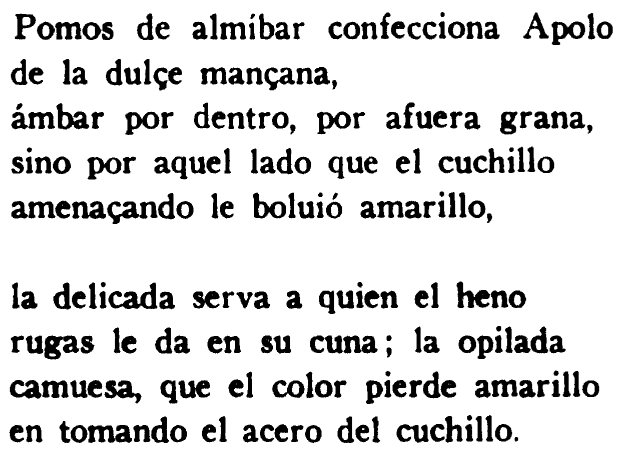

Blecua razona su hipótesis de la siguiente manera:

Creo que la coincidencia, hasta en la rima, no puede ser más exacta. El Polifemo, en su relación primitiva, fue leído en Zaragoza, ya que la misma variante se encuentra en la versión copiada en nuestro cancionero (...) y cabe muy bien suponer que el círculo gongorino aragonés conociese también la corrección introducida posteriormente. Podemos, pues, colocar la fecha de la redacción de la primera de las Selvas entre 1613 y 1628, sin temor a equivocarnos. (José Manuel Blecua [1945], págs. 25-26).

Aurora Egido es quien más ha trabajado sobre los elementos gongorinos del poema de Ginovés y compara dos nuevos pasajes en los que la imitación es evidente. Son los siguientes ([1979] págs. 217-218):

$$
\begin{aligned}
& \text { Bufones son los estanques } \\
& \text { y en qué lo son diré: } \\
& \text { en lo frío lo primero } \\
& \text { que se me ha de conceder; } \\
& \text { en el murmurar contino } \\
& \text { y en el reírse también } \\
& \text { aunque hacen poco ruido } \\
& \text { con ser hombres de placer, }
\end{aligned}
$$

(Góngora, El palacio de la primavera [1609]) 
Sigue al Abril su próvido ministro, el Céfiro lijero, que por ser su privado es lisongero, y aun bufón tan gustoso que no pierde por frío el ser gracioso, (Ginovés, Selva, vv. 53-57)

Meninas son las violetas y muy bien lo pueden ser.

(Góngora, El palacio de la primavera)

salen ya madurando las perillas,

de todas las primeras, que por ser de la reyna y ser tan niñas, parecen las meninas de las peras.

(Ginovés, Selva, vv. 283-6)

Aurora Egido concluye:

Sigue el lenguaje entre marcados límites gongorinos: el uno abundante del bimembre, ya sea antitético, fonético, simétrico, etc., con algunos trimembres, cultismos y otras fórmulas estilísticas... ([1979] pág. 220).

Hasta aquí lo que la crítica ha extraído del gongorismo de Ginovés. En realidad, poco más se puede concluir, salvo seguir comparando pasajes pararelos e incluso versos aislados.

$\mathrm{Y}$ esto último es lo que nos proponemos realizar en este momento.

\section{II}

Los ríos, como los cielos o los insectos, constituyen una de las páginas del libro del mundo en el que se puede leer el mensaje de armonía y unidad que la naturaleza nos enseña.

Las Selvas de Ginovés, tras las huellas de las Soledades gongorinas, prosiguen una tradición muy antigua que engarza directamente con la pastoral, cuya raíz psicológica - como ha manifestado Renato Poggioli- es "una doble necesidad de inocencia y felicidad, que deben ser recobradas no a través de la conversión o regeneración, sino simplemente a través de un retiro" (Poggioli [1975], pág. 119). Cascardi ha analizado este problema con detenimiento, para llegar a la conclusión de que se trata de "un sueño" que "es creado muy frecuentemente por un habitante de la ciudad" (Cascardi [1980], pág. 119).

El recuerdo del paraíso perdido, la fantasía de la Arcadia posible, leída y soñada, hace que el hombre vuelva a la naturaleza con objeto de encontrar en ella la armonía, la perfección que el Arte le ha conferido tan frecuentemente. De esta manera, Naturaleza y Arte se funden en un mismo propó- 
sito de equilibrio. Es un tópico decir - aunque no sea del todo cierto- que "el Renacimiento se sacudió el polvo de los viejos pergaminos a fin de leer en el libro de la naturaleza o del mundo" (Curtius [1981], t. I, pág. 448).

$Y$ toda esta fusión Naturaleza-Arte nos lleva a un punto central en nuestros poemas: la poesía descriptiva, "que atiende a la relación del hecho, al cumplido recuento de la belleza artística, o al análisis minucioso del paisaje", y que "constituye una de las claves de la poesía aragonesa del siglo xviI" (Egido [1979], pág. 211). Bajo la dirección de los Argensola y, sobre todo, capitaneados por el modelo gongorino, los poetas aragoneses del barroco componen

Desengaños de vida cortesana, alabanzas de soledad en el campo, lucha abierta contra el paso del tiempo, añoranza del Paraíso o de la Arcadia... y, sobre todo, naturaleza hecha textos, viva sólo en muy contados versos, escasamente individualizada y sujeta a las normas del precepto. "Que el arte ayuda a naturaleza", como quería Alciato (Ibidem).

Pero lo que nos interesa no es llegar a definir la poesía descriptiva - esto ha sido hecho con bastante detenimiento-, sino llegar a determinar la causa que puede mover al hombre barroco a componer estos poemas de añoranza y soledad. Beverley, en el prólogo a su edición de las Soledades, dice que el poema gongorino refleja el sentir del hombre inmerso en la España de la decadencia imperial; de aquí el menosprecio de la Corte y consiguiente rechazo del pastor hacia la empresa colonial. A través de los versos selváticos, "el poeta se retira de la presión inmediata de las circunstancias hacia cotro mundo»" ([1980] pág. 26). "El alejamiento en el arte significa una búsqueda de la imagen de una utopía que puede contraponerse a la experiencia histórica del desastre" (Ibidem).

Pero hay una diferencia radical entre el poema gongorino y el de Ginovés que conviene tener presente en todo momento, a saber, el aragonés es un poeta de lo familiar y cotidiano, el cordobés universaliza en categorías acrisoladas todo cuanto toca, de tal forma que nada vuelve a ser lo mismo desde el momento que lo ha re-inventado a través de la palabra. $Y$ esto se demuestra mucho más en las Soledades, pues como dice Maurice Molho:

Góngora escribe un poema bucólico: los seres que pone en escena - pastores, pescadores, árboles, pájaros, objetos familiares, etc.- son unos "universales" que, en virtud de una perfección poética propia y no bajo la especie de su cotidiana singularidad, se proyectan en un absoluto imaginario en el que se transforman en entidades concebibles. (Maurice Molho [1978], pág. 24).

Ginovés entendió - aunque no siempre imitó bien- la soledad como metalenguaje y como huida de la realidad. Le importaba mucho más el 
trasfondo ideológico del poema gongorino que ninguna otra cosa, dado que, de esta forma, podía imitar largos pasajes para componerlos en una claridad distinta. con su sentido diferente y, sobre todo, con una contingencia más cercana y aparente.

$\mathrm{La}$ imagen del río como discurso es una de las coincidencias entre las Soledades gongorinas y las Silvas de Ginovés. No vamos a entrar en los orígenes de la metáfora, baste saber que se basa en que

el mundo es un texto, una escritura, que los hombres desciframos o leemos. Las casas, los árboles, los ríos, los hombres, son renglones de una escritura, la escritura de la naturaleza. Líneas precisas o desdibujadas, oscuras o claras, ordenadas o tal vez confusas, superpuestas; líneas inteligibles o ininteligibles. Podemos leer en ellas como en un libro; mejor dicho, esas líneas son un libro, el libro. (Sánchez Robayna [1983], pág. 37).

Veamos, pues, cuáles son los pasajes en los que encontramos las imágenes fluviales que intentamos comparar. El de las Soledades plantea una serie de problemas que analizaremos más adelante; el texto, tal y como lo edita Dámaso Alonso (1982), es el siguiente:

Muda la admiración, habla callando

y, ciega, un río sigue, que -luciente

de aquellos montes hijo-

con torcido discurso, aunque prolijo,

tiraniza los campos útilmente;

orladas sus orillas de frutales,

si de flores, tomadas, no, a la Aurora,

derecho corre mientras no provoca

los mismos altos el de sus cristales;

huye un trecho de si, y se alcanza luego;

desvíase, $\mathrm{y}$, buscando desvíos,

errores dulces, dulces desvaríos

hacen sus aguas con lascivo juego;

engarzando edificios en su plata,

de quintas coronado, se dilata

majestuosamente

-en brazos divididos caudalosos

de islas, que paréntesis frondosos

al período son de su corriente-

de alta gruta donde se desata

hasta los jaspes líquidos, adonde

su orgullo pierde y su memoria esconde

(vv. 197-218)

El texto de la Silva de Verano de Ginovés, tal y como lo edita Blecua, es el que sigue:

Ya alegre se dilata,

culebreando sobre el verde prado, 
sierpecilla de plata, el arroiuelo, desenroscando del pesado yelo; ya juguetón saltando, va con las verdes yerbas retoçando, $y$ entre dientes de guixas lisonjero, rie en Abril lo que lloró en Enero. Ya fácil por la arena haciendo va vn discurso tan prolixo, desde el primer principio de su fuente asta consecuencia del tridente, que al ojo muestra mil verdades claras. Si en su discurso diáphano reparas, el orgulloso son de su corriente es de las aues cítara arjentada, pues siguen con su canto placentero el fiel compás de su christal parlero.

(ed. Blecua [1945], págs. 194-207)

Los problemas a los que aludíamos anteriormente se centran en las variantes existentes en el pasaje de las Soledades, dado que se trata de uno de los tres pasajes de esta obra censurados por Pedro de Valencia y que Góngora corrigió (D. Alonso [1927]). La versión editada por Alonso no se ajusta ni a la versión original (al menos en su integridad) ni a la versión "definitiva". Veamos, la versión más antigua dice:

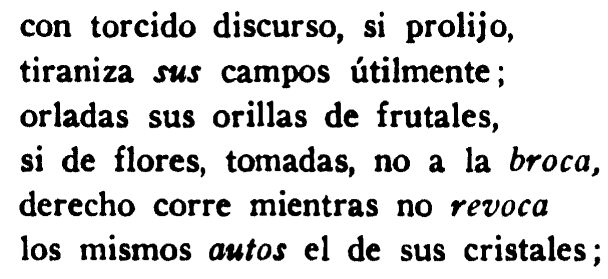

Ciertamente, las diferencias en este caso son mínimas, pero suficientes para destruir la gracia introducida por medio del lenguaje jurídico (revocar los autos); empero, sí que son muy numerosas las diferencias encontradas con la versión definitiva, hasta el punto de que prácticamente no coinciden más que los versos iniciales y los finales:

con torcido discurso, aunque prolijo, tiraniza los campos útilmente; orladas sus orillas de frutales, quiere la Copia que su cuerpo sea (si al animal armaron de Amaltea diáfanos cristales);

engarzando edificios en su plata, de muros se corona, 


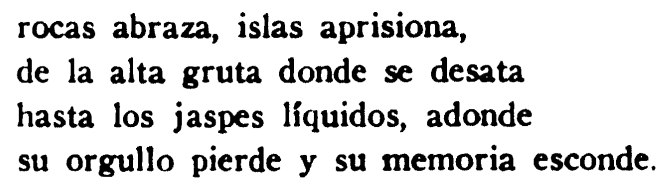

Analizados con detenimiento los pasajes de las Soledades, y si los comparamos con los versos citados de Ginovés, podemos observar que el poeta aragonés se sirvió de un texto que contenía la Soledad Primera en su versión más antigua, porque las coincidencias se acentúan, incluso, en la utilización de ciertos términos (prolijo, discurso, cristales, plata, son, corriente, dilata), aunque la coincidencia mayor sea común a las dos versiones (con torcido discurso, aunque prolijo, en la Soledad Primera; haciendo va vn discurso tan prolixo, en la Silva).

Todo esto no nos lleva más que a ahondar en una idea ya apuntada por Blecua en su edición del Cancionero de 1628 al comparar los versos 287291 de la Silva con otro pasaje censurado por Pedro de Valencia, correspondientes, esta vez, al Poliferno: el poema de Ginovés se escribió muy poco después de aparecer la primera versión de la Soledad Primera (1613); casi me atrevería a decir que la Silva al estío se compuso como una réplica al poema gongorino. También nos demuestra que la versión primitiva de las Soledades fue muy difundida en Zaragoza, tal como lo confirma el texto del Cancionero de 1628 , en el que se recogen los grandes poemas del cordobés sin las correcciones posteriores.

Las diferencias entre los pasajes son obvias; sin embargo, vamos a detenernos en el análisis de las mismas porque a través de ellas pueden observarse distintas actitudes poéticas.

De entrada, debe quedar bien claro que existe un abismo insondable en lo que concierne a la calidad poética. Los versos gongorinos están llenos de lírica descripción y de sostenida belleza; los de Ginovés se pierden en ocasiones en prosaísmos innecesarios, en metáforas poco acertadas y en repeticiones desafortunadas. Con todo, incluso en los errores pueden comprobarse las características de cada poema, por tratarse de dos pasajes muy significativos en cada uno de ellos.

Aurora Egido nos dice del poema de Ginovés :

En el estío, Ginovés retomará la senda culterana, hablará de la naturaleza cambiante y sometida a las normas de las estaciones. Paisaje sin figuras, sometido al "decreto fatal del tiempo alterno" y que se define por oposición a los rigores del invierno, estableciéndose así todo tipo de antítesis, entre el calor y el frío, la oscuridad y la luz. (Egido [1979], pág. 217).

$\mathrm{Y}$ esto es lo primero que destaca del paisaje transcrito: su intento de reflejar la movilidad del río, su "naturaleza cambiante", su devenir contiLXVIII, $10^{0}-2 .^{\circ}-9$ 
nuado en un fluir sin descanso. Abundan los adverbios de tiempo, en un intento de ir recogiendo en instantáneas fotográficas todos los momentos en los que el 'arroiuelo' es para dejar de ser prontamente; el devenir heracliano se manifiesta, de esta manera, sobre todo mediante la inclusión de ya anafórico:

$$
\begin{aligned}
& \text { Ya alegre se dilata } \\
& \ldots \\
& \text { ya juguetón saltando } \\
& \ldots \text { Ya fácil por la arena }
\end{aligned}
$$

Por medio de la presencia de los adverbios de tiempo consignados se intenta que el lector "presencie" la movilidad del arroyo en tres momentos de "su eterna estrofa". Pero detengámonos un poco más y observemos las formas verbales presentes en el pasaje analizado:

$\begin{array}{ll}\text { se dilata } & \text { haciendo } \\ \text { culebreando } & \text { va } \\ \text { desenroscando } & \text { muestra } \\ \text { saltando } & \text { reparas } \\ \text { retozando } & \text { es } \\ \text { ríe } & \text { siguen } \\ \text { lloró } & \end{array}$

Hay un predominio claro de los verbos que indican una idea de movimiento (se dilata, culebreando, desenroscando, saltando, siguen), con lo que se recalca la sensación del flujo. Pero, al mismo tiempo, una gran parte de las acciones verbales corresponden a acciones propias del hombre. Existe, así, una aparente contradicción entre la descripción de un "paisaje sin figuras" y el intento de humanizar las acciones de la Naturaleza; el arroyo salta, retoza, se rie, llora, etc., en un deseo de demostrar que la Naturaleza se rige por las mismas leyes que el hombre, ya que no es sino una muestra a menor escala del propio cosmos (Rico [1970]). La naturaleza se nos presenta en el mismo momento en el que se produce la metamorfosis; como en el hombre, los cambios de humores hacen que los sentimientos varien. Pero lo curioso es que toda esta transformación se realiza ante nuestros ojos, como en el epigrama "De rosis nascentibus", de Ausonio, con el cual también tiene ciertas coincidencias.

Lo que nos interesa destacar ahora es que, como en el poema ausoniano, el círculo de comunicación no se cierra en una experiencia particular, sino que se invita al lector-espectador a participar en ese cambio continuo que se opera en la naturaleza. (Si en su discurso diáphano reparas). Me detengo en este punto por considerar que las diferencias entre el poema de Gi- 
novés y el gongorino son, en parte, las mismas que existen entre el epigrama de Ausonio y la oda de Horacio "Ad Leuconoem", aunque en unos niveles significativos y poéticos diferentes.

En la composición de Ausonio vemos las rosas que nacen al amanecer, el rocío, las huertas, el olor a azafrán, las hierbas curvadas, las coles entreabiertas..., todos los elementos de una naturaleza real y cotidiana, familiar y doméstica. Se ocupa de describir lo diminuto, las cosas menos transcendentes, los frutos más humildes. Todo está en armonía, pero todo lleva implícita la muerte:

Rara pruinosis canebat gemma fructectis ad primi radios interituta diei.

(Ausonio)

tempranas nacen y tempranas mueren

(Ginovés)

Pero en Ausonio, el rocío, la bella perla de escarcha que cubre las coles, la belleza de la rosa al nacer al día..., todo se muestra en una belleza dinámica que tiene un ciclo vital muy corto. Para el poeta latino de Burdeos la vida comienza cada mañana; para el aragonés, en la primavera. La muerte, por consiguiente, es en Ausonio la noche y en Ginovés "la noche del invierno cano" (verso 8). En la Silva se observa un ensanchamiento del ciclo vital, que se extiende del mínimo renacer del día a las estaciones del año. La descripción se efectúa con símiles en los que se incluye el ciclo vital mínimo, acercándose a Ausonio:

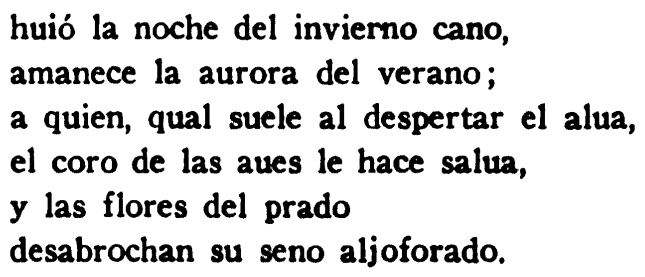

En ambos casos, se trata de una experiencia particular, pero de ella se saca una máxima universal; en ambos casos se nos invita a participar de esa vida pletórica.

La experiencia de todo ello podría ser el rápido envejecimiento de lo bello y, por eso, la conclusión, implícita o explícita no se deja esperar:

\footnotetext{
Mirabar celerem fugitiva aetate rapinam, et dum nascentur consenuisse rosas.

...

Ecce et defluxit rutuli coma punica floris dum loquor, et tellus tecta rubore micat.
} 
Tot species tantosque ortus variosque novatus una dies aperit, conficit ipsa dies.

Conquerimur, Natura, brevis quod gratia florum: ostentata oculis ilico dona rapis.

Quam longa una dies, aetas tam longa rosarum, quas pubescentes iuncta senecta premit.

Quam modo nascentem vesere vidit anum.

Sed bene quod paucis licet interituta diebus succedens aevum prorogat ipsa suum.

Collige, virgo, rosas dum flos novus et novas pubes et menor esto aevum sic properare tuum.

En la Silva esta conclusión está implícita a lo largo de todo el poema, o, mejor dicho, en la misma filosofía que lo engendra. Las alusiones a una muerte inmediatamente anterior, de la cual se acaba de resucitar, son harto frecuentes :

la verde pompa restituie al año

$\cdots$

mortaja y luto al resplendor de Delo,

que por muerto con lluvias llora el cielo;

$\cdots$

despierta el claro día,

aún bosteçando del pasado sueño,

que, al fin, de las ceniças del inuierno,

el Phénix de los meses,

el Abril florescente, resucita

ríe en Abril lo que lloró en Enero.

Las violetas, primicias del verano (...)

tempranas nacen y tempranas mueren

que entre las flores, cuia frente erguida

vn breue aliento aun breue sol trabuca,

no implica el ser niña al ser caduca;

mas no imprudentes en salir tempranas

expuestas al rigor de las mañanas

(vv. 117-125)

los almendros madrugan (...)

que por ser los primeros de los frutos

Aquilón proceloso los combate,

castigando con rígida violencia

la afectada ambición de precedencia;

que esto de pretender el primer puesto,

asta en las plantas se malogra presto.

(vv. 233-243) 
Muerte y resurrección; la conclusión de todo ello no puede ser más que la incitación, la exhortación, mejor, a vivir con intensidad la vida, la belleza, abandonando los peligros que acosan al hombre que no sabe disfrutar de cuanto le rodea. En este orden de cosas, es típica en las silvas la aparición de un personaje-patrón al que se dirige el poema y al que se le recomienda horacianamente que huya de los riesgos de la ciudad y se acerque a la naturaleza. Asi puede observarse en las Soledades. Aurora Egido nos dice al respecto sobre el poema de Ginovés:

Como en "Appleton House" de Marvell o en las Soledades gongorinas, la Naturaleza es compartida por alguien a quien se dirige el poema (Lord Fairfax / Duque de Béjar), aunque aquí se preste a invitación horaciana a un tal Diego, para que huya de los peligros de la ciudad. ([1979] pág. 220)).

Esta invitación, empero, no está presente en la Silva del Verano, sino que forma parte de las Silvas de todo el año, que aparecieron impresas en 1688, "imprimiéndose después junto con las obras de Gracián” (Blecua [1945], pág. 24); por lo que, si consideramos la Silva al Verano como un poema independiente que, posteriormente, fue integrado en un conjunto más amplio, no aparece el interlocutor directo. Más probable es que la dedicatoria sea posterior a la composición del poema y que la exhortación que nos hace el autor a la percepción de esa naturaleza viva y cambiante vaya dirigida a todos los posibles lectores. Se trata, evidentemente, de una ficción literaria, de un mero juego de enredo, pero - al igual que en el "Ad Leuconoem" horaciano- en las Soledades se describe la aventura de un héroe en un relato que va destinado a un receptor concreto y determinado y que conforma un círculo de comunicación en el que, deliberadamente, estamos excluidos el resto de los lectores. Según mi modesto parecer, esto no ocurre de igual manera en la selva de Ginovés, la cual - al igual que el epigrama de Ausonio- posee un círculo comunicativo mucho más amplio; la experiencia particular se universaliza. Pero detengámonos en este punto.

En los 309 versos de la Selva al verano, Ginovés no muestra ni la más mínima huella del yo del narrador; ningún verbo en primera persona, aunque sí ciertos diminutivos que pudieran indicarnos la sensibilidad de este personaje. Por el contrario, en la Soledad Primera de don Luis el narrador aparece en dos ocasiones, y las dos dudando:

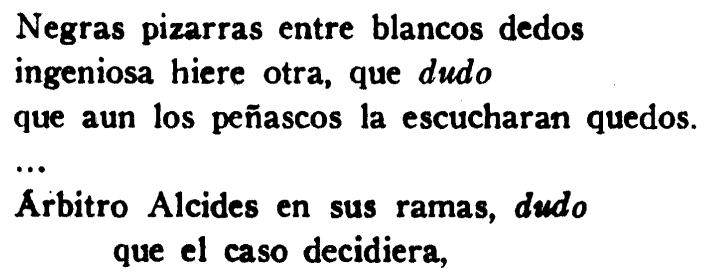


Sin embargo, el poeta aragonés dirige en dos ocasiones el discurso hacia sus interlocutores, aunque de forma particularizada:

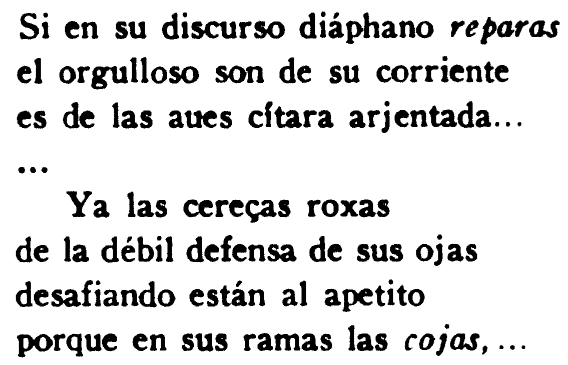

(vv. 244-7)

Con el último pasaje, vemos cómo Ginovés llega a la incitación más directa, poniéndonos delante de los ojos esos sabrosos frutos que la naturaleza ofrece en el verano, recordándonos que están ahí, en las lozanas ramas de los árboles, recién florecidos, para regalarnos con su belleza y degustación.

También Góngora dirige, aunque proporcionalmente en menos ocasiones, su discurso a un tú, interlocutor ausente:

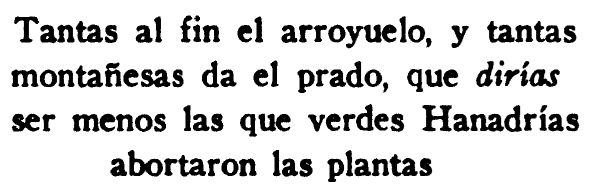

Sin embargo, ese tú está localizado y no hace otra cosa que reducir, más todavia, el canal de comunicación. Horacio dedica su Oda XI a Leuconoe, es a ella a quien exhorta al carpe diem, se trata, pues, de una composición muy reducida; la desconfianza total en los dioses hace que el autor desconfíe también de los horóscopos y prefiera adoptar una postura escéptica; se resigna a aceptar pacientemente lo que viniere y a no querer conocer nada (scire nefas dice Horacio a su interlocutora); la referencia al amor en la oda de Horacio es muy ligera, no le interesa centrar el tema sobre este punto, sino que lo relega para dejar pasar al que él considera motivo principal: el paso del tiempo y la falta de defensas que tiene el hombre ante un futuro incierto. El razonamiento de Horacio es axiomático y su estructura es aristotélica en su más pura simpleza: 'Puesto que ni los dioses ni la astrología te sirven, y puesto que vives en la más completa incertidumbre, goza del día'. El círculo de comunicación está perfectamente cerrado; es un proceso que va de lo aparentemente universal a lo particular, a un caso concreto.

De idéntica manera opera Góngora; dedica su poema a un tú concreto, a quien narra los pasos "errantes" de su peregrino. Su filosofía está im- 
pregnada de epicureismo horaciano, hasta tal punto que Azorin manifestaba que se podía reflejar en un verso: "goza el color, la luz, el oro", del soneto "Ilustre y hermosísima María" (Martínez Ruiz [1912]). El carpe diem podría perfectamente resumir la trayectoria poética gongorina.

Y quizás sea ésta la diferencia más relevante de los dos textos de Góngora y Ginovés que estamos intentando comparar. Pero no podemos olvidar que el horacianismo de don Luis le obliga a adoptar una postura de mesura sentimental, de desapasionamiento y de alejamiento sopesado con respecto al objeto narrado. Frente al frenesí del aragonés, manifestado en versos desenfrenados, el cordobés enfrenta su "admiración muda", que es la misma que la de su protagonista.

Góngora nos muestra un río juguetón pero pausado, controlado desde la altura por la mirada dominante del héroe peregrino, que re-crea el paisaje con su predominio visual cercano a la aseidad divina. Ginovés, por el contrario, se deja llevar por el apasionamiento que le produce la admiración y el asombro de cuanto está presenciando, porque comprende ahora que también con la vista puede llegar a entender los tesoros de la naturaleza ; el paisaje (... al ojo muestra mil verdades claras, v. 73). Por eso, trata de captar cada uno de los momentos del cambio continuo que le ofrece el arroyo, cada una de sus imágenes.

Aunque parezca mentira, en Góngora se siente la presencia humana, frente al poeta aragonés que nos ofrece una composición en la que el elemento humano no aparece más que como materia poetizadora, como componente metaforizador. De esta manera,

este poema ofrece la particularidad de estar descrito en términos pictóricos y de ofrecer una naturaleza independizada de la figura humana, lo cual sólo se da con frecuencia a partir del siglo xviII, para alcanzar plena independencia en el Romanticismo. (Egido [1978], págs. 33-34).

Acabaremos este repaso-comentario del pasaje señalado con las palabras del crítico que nos ayudó a iniciarlo:

La calidad sugestiva de estos versos no puede hacernos olvidar que Góngora habla aquí tanto de una naturaleza escrita (la escritura del mundo) como de la escritura del poema. Metalenguaje. Sistema doble de alusión mediante el cual aquel que escribe de la naturaleza que es una escritura está aludiendo simultáneamente a la propia escritura. El río que se desliza entre islotes -el río escrito- es, también, el fluomen grationis.

Islas-paréntesis, período-corriente. El libro del mundo está escrito con los mismos caracteres de la escritura que lo refiere; el "prolijo discurso", del río es, en fin, el discurso mismo del poema (...). Texto y mundo recubren, en esos versos, un idéntico espacio: curso-discurso de la escritura-mundo. (Sánchez Robayna [1983], pág. 41). 
Ginovés intenta seguir a su maestro en esta metáfora continuada y, a decir verdad, que en este pasaje consigue unos versos de poesía de suficiente calidad como para merecer la pena detenerse en él.

\section{III}

Hay, empero, otro fragmento de las Soledades que pudiera recordarnos el pasaje de Ginovés por la coincidencia de algunos elementos:

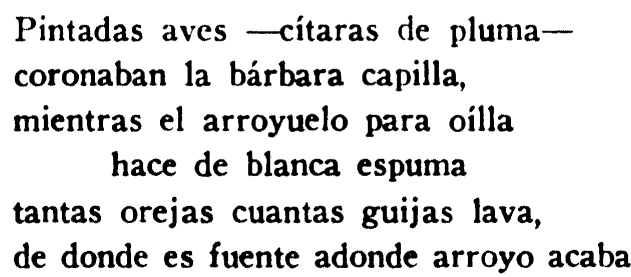

(Sol. I, vv. 562-7)

De los diez sustantivos presentes en estos seis versos, cinco están presentes en el pasaje de Ginovés (aves, citaras, arroyuelo, guijas y fuente); alguno de ellos, incluso, con una sufijación inusual (arroyuelo, que aparece en alguna otra ocasión en la Soledad Primera, como en el verso 266) y la mayor parte de los restantes son harto frecuentes en la Selva (salvo capilla, los demás aparecen en más de una ocasión). La cercania de los términos aves y citara tampoco es casual; ha variado el referente al que se ha aplicado la metáfora, pero el proceso es el mismo: en Góngora, son las aves las cítaras; en el aragonés, la cítara argentada es el arroyuelo que alegra con "el orgulloso son de su corriente" a los mismos pájaros. Las guijas son, en don Luis, orejas de espuma; en Ginovés, los dientes que muestran la risa del arroyo. El verso último del pasaje gongorino también aparece en el autor de la Selva al estio, aunque amplificado y algo disminuido en lirismo.

desde el primer principio de su fuente asta la consecuencia del tridente.

Por otra parte, el símil sinestésico que asimila el sonido de la corriente del arroyo con instrumentos musicales, es continuado, no siempre felizmente, por nuestro Ginovés, que concluye, de esta manera, un pasaje de poesía de verdad. 


\section{IV}

Otra de las coincidencias - no me atrevo a hablar en este caso de influencia- entre las Soledades y la Selva al Estio de Matías Ginovés consiste en incluir los dos un pasaje en el que se describe, con mayor detenimiento en el texto del licenciado, la labor de las abejas, haciendo que el ojo del narrador-observador efectúe una introspección microscópica, y se nos relate, con todo detalle y amor por lo más pequeño, la provechosa vida de estos insectos.

Las abejas, como miembros de la especie de los insectos, forman también parte del gran libro de la naturaleza, tal y como nos recuerda Curtius:

El libro de la naturaleza contiene muchas páginas; una de las más curiosas es la que trata de los insectos (Curtius [1980], t. I, pág. 453).

También las abejas tienen mucho que enseñarnos. Pero veamos los textos.

El de Ginovés dice así :

Apenas de este modo

con las flores se puebla el campo todo,

quando las abejuelas,

de sus dulces reales retiradas,

marchan arracimadas

en escuadrón errante;

dando señal su trompa susurrante,

embisten animosas

al exército bello de las flores,

executando en ellas sus rigores,

asta que sus dulcissimos despojos

vsurpan, y con ellos,

por diferentes sendas,

cargadas bueluen a sus ricas tiendas,

depositando en el común erario

la dulce presa entera,

en caxoncitos de labrada cera.

Mas no por esto quedan

las flores de los fértiles frutales

tan despojadas de dulçuras tales,

que no se queden con vn buen pedaço

que aquestos dulces bienes,

con que después de muertas,

los frutos, sus hijicos,

quedan de miel y de dulçura ricos. 
En la Soledad Primera las abejas aparecen en un pasaje mucho más breve :

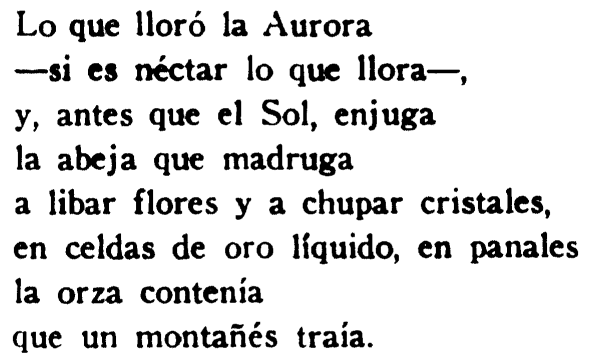

En el mismo poema gongorino aparece una comparación metafórica en la que la abeja es el elemento sustituyente o irreal; se trata del novio, a quien se desea felicidad en la consumación de su matrimonio:

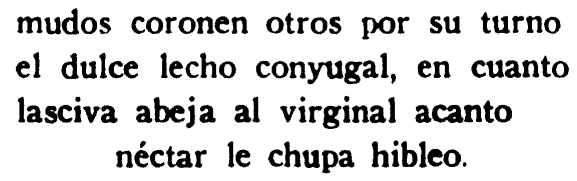

En realidad, poco o nada hay que decir. Los pasajes son paralelos; quizás Ginovés pensase en el texto gongorino para componer el suyo, pero creo que queda bien claro con la sola lectura de los versos que para nada los tuvo presentes, ni tan siquiera para intentar emular la plasticidad y la poética belleza del andaluz.

Lo único destacable del fragmento de Ginovés es que, inusualmente, está descrito con abundantes términos bélicos. Las abejas son un escuadrón errante; los panales, que reales retiradas; embisten animosas / al ejército bello de las flores al toque de la trompa susurrante; ejecutan la batalla y usurpan los despojos de sus enemigas las flores, que guardan como presas en sus tiendas. Pese a todo ello, la lucha entablada es una lucha redimidora, ya que de ella surge la vida y no queda la muerte como recuerdo infinito de la irracional batalla. Se trata de la muerte que da vida, del amor que hiere, consecuencia de los cuales serán los dulces frutos que se nos ofrecen.

Egido nos recuerda que las imágenes bélicas son usadas frecuentemente por Ginovés para describir la estación invernal, "símbolo de la tiranía y la negación de todo" ([1979] pág. 220). También nos resume su quehacer:

A ratos se hace miniaturista y elabora las imágenes con curiosas referencias a telas, piedras y joyas, porque lo que le interesa es la minimización de ese paisaje abundante, recién salido del invierno, visto con óptica microscópica, deteniéndose en las abejas, en los pequeños insectos que abrigan, en su brevedad, belleza y lección. Los restos de bucolismo clásico aparecen en su hori- 
zontalidad armónica soportando una naturaleza que sirve como medida al hombre, pero es descrita en términos de orfebrería y artificio (...). En Ginovés no está planteada en términos de lucha, sino en perfecto equilibrio... ([1978] págs. 35-36).

Efectivamente, pese a que los términos empleados en la descripción del pasaje que comentamos sean, en su mayor parte, bélicos, el contexto, el resultado final es que los versos, una vez leídos, producen una sensación de equilibrio y lucha mesurada, necesaria, pero amorosa. Es la ley de la naturaleza: es necesario que haya muerte para que resucite la vida mucho más hermosa, lozana $y$ radiante en su nueva andadura, redimida de sus antiguos defectos, vivificante.

Por el contrario, los versos de Góngora son violentos no por la significación de las palabras que incluyen, sino por su propia estructura sintáctica y por la inclusión de la duda que rompe el perfecto equilibrio alcanzado por medio de ese metalenguaje que tanto le ha costado construir $y$ que ha llegado a configurar una estructura coherente de lenguaje en esencia.

No podemos olvidar, a este respecto, que

La originalidad de Góngora está en sobrepasar el lenguaje que ya no es para él tan sólo material de imitación, sino modelo profundo del poema. La poética gongorina consiste, en realidad, en generalizar los objetos que encuentra, es decir, en inscribir lo que percibe en un concebir abstracto que es un campo extensivo de relaciones (Molho [1978], pág. 25).

Al introducir Góngora ese verso en el que cuestiona uno de los axiomas de su proceso poético (-si es néctar lo que llora- la Aurora), está poniendo en duda todos y cada uno de los principios en los que se sustenta su labor artística. No es esto algo novedoso en el cordobés, que aprovecha cualquier ocasión para desdecirse, destruir el precioso palacio de cristal construido tras enormes esfuerzos de imaginación y derroche de plasticidad. El problema se traspasa a los seguidores ciegos del maestro, que, a veces, no son capaces de darse cuenta de la verdadera transcendencia de la poesía de Góngora. Así, Ginovés hace derrochar lágrimas a la Aurora, al cielo, a Apolo, a todo aquel que se le presente; lloro y risas se combinan alegremente hasta reflejar la metamorfosis de la naturaleza:

\footnotetext{
...llorosa

huió la noche del invierno cano

que por muerto con lluvias llora el cielo;

...

el Alua entre modestos resplandores,
} 


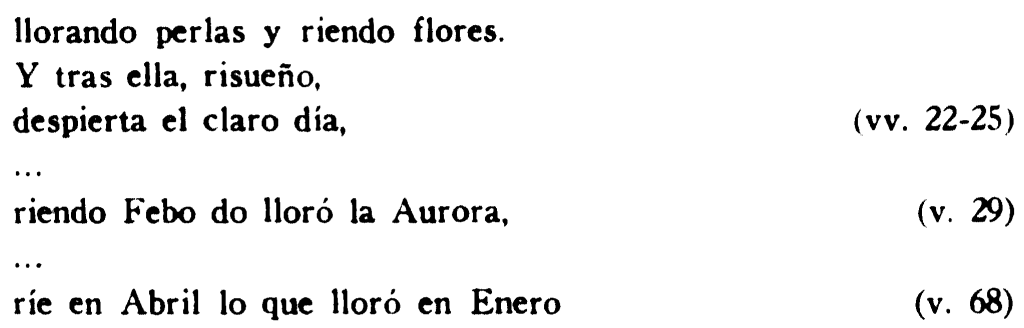

Es la eterna bienaventuranza de los seguidores ciegos, que exageran y santifican los defectos del maestro. $Y$ eso que Ginovés abandona la senda gongorina en otras composiciones o las atenúa a su medida más ecuánime.

Poco que decir del pasaje comentado, salvo recalcar la labor de descripción microscópica que hace Ginovés e incidir en esa aparente contradicción en la que la lucha relatada en términos bélicos concluye en una armonía redentora y equilibrada.

\section{V}

El último de los pasajes que queremos comentar de la Selva al verano de Matías Ginovés no tiene un paralelo exacto en las Soledades gongorinas, aunque si ciertas similitudes, más ideológicas que de ninguna otra índole, con algún fragmento de la Soledad Primera. Nos referimos a los versos 186-199:

Con esta alegre confusión de flores, cubierto el fértil suelo pretende hacer emulación al cielo;

si ya no vn fiel traslado

de todo aquesse exército estrellado:

soles son los claueles,

lunas las açucenas,

el aurora, la rosa, que alegría

derrama al despuntar del claro día, toda la plebe de las flores bellas,

que sobre el epiçiclo

del capullito tierno y delicado,

fragantes raios dan al verde prado.

Lo que nos interesa destacar de este fragmento es la trasposición que el poeta ha efectuado: las flores componen un universo perfectamente dispuesto; son un traslado, una copia del mismo Universo, del cosmos, una "emulación del cielo", como nos dice el autor. En realidad, poco puede extrañarnos esta alegoría sostenida, ya que en Góngora son frecuentes las 
comparaciones cósmicas : cualquier objeto brillante es el sol; la blancura es la luna; estrellas son las partículas del agua, etc. Sin embargo, no encontramos en el cordobés ninguna imagen sostenida en la que se efectúe este traslado cielo/suelo de forma tan precisa. La descripción es parecida a la de las flores en el Palacio de la Prinavera del mismo Góngora.

Sin embargo, este traslado sí que se encuentra en varios seguidores del poeta cordobés. Así, en Soto de Rojas:

Los fenices de Alcín, lisonjas bellas

que en sus flores trasladan las estrellas (Paraiso..., vv. 33-44).

Emulación es la palabra clave; copia directa del universo, del cosmos, es la naturaleza, el hombre mismo. La ley universal es la misma siempre y los mismos axiomas mueven todas las cosas del mundo. Por eso, el hombre debe apartarse del mundo cortesano y ciudadano, antinatural por su hipocresía mal disimulada, y volver a la naturaleza a aprender el misterio de las flores más caducas. Pero, al mismo tiempo, el mismo poema es - debe ser- un traslado de ese mundo mal conocido, y el Arte, por ende, se convierte en un saber aplicar las leyes universales de la naturaleza a las palabras. Naturaleza y arte se vuelven a fundir, pero ahora en un proceso inverso y complementario.

Las aves "siguen con su canto plaçentero / el fiel compás de su christal parlero" (el cristal del arroyo) en Ginovés, las aves gongorinas, más atrevidas, escriben en el mismo cielo:

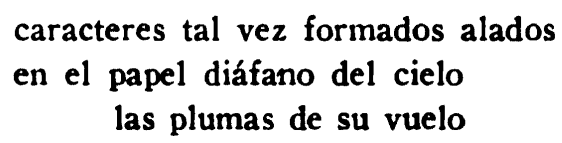

(Sol., I, vv. 616-618)

Sánchez Robayna lo comenta:

La calidad idiográmica de la metáfora gongorina aparece súbitamente ahondada, en su intensidad visual, fanopeica, en la referencia al "papel del cielo". Góngora pone fondo a los "caracteres", a las letras-aves convirtiendo así la metáfora en una verdadera escritura (más allá de la analogía); cierra, de este modo, la metáfora para intensificar la visión del mundo escrito, de la escritura del mundo (Sánchez Robayna [1983], pág. 46).

\section{VI}

También aparecen frecuentes alusiones a la artesanía y al bordado. Así, las flores "desabrochan su seno", Orión "texe" "sobre el telar del aire frío" (vv. 13-15) o las abejas depositan la miel en "caxoncitos de labrada 
cera" (v. 216). También son comunes, aunque no sean tan abundantes como en la poesía gongorina, las referencias a las piedras preciosas, capítulo éste que no necesita de comentario alguno por seguir las metáforas ya lexicalizadas del cordobés.

Consideración especial merece tener la humanización del paisaje que hace Ginovés. En la Selva al verano el mundo se nos presenta como una gran figura humana. Veamos algunos casos:

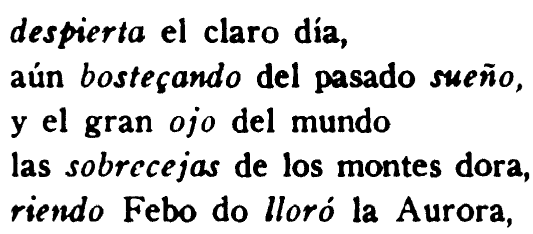

(vv. 25-29)

El Moncayo tiene canas que peina el viento (vv. 33-34); Abril pisa los campos; el Céfiro es privado, lisonjero y bufón (vv. 48, 54-56), etc. "Paisaje sin figuras", como decia Aurora Egido, pero también figura en el paisaje, unidad descriptiva que se ordena siempre de igual manera.

Esta humanización llega al extremo de hacernos ver una naturaleza viva, con cuyos elementos podemos, incluso, conversar:

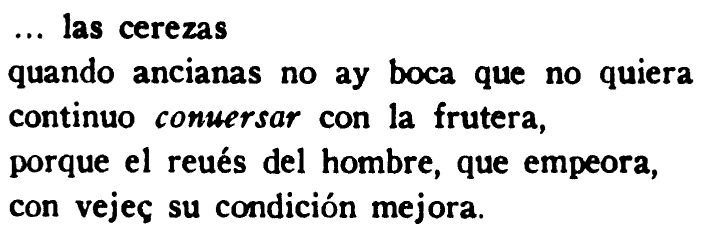

(vv. 298-299)

Hay leyes particulares, pero nunca contradicen la universal. No falta la equiparación poesía-pintura, hábilmente dispuesta aquí junto a la imposibilidad de describir-pintar la belleza inefable con la exactitud requerida:

$$
\begin{aligned}
& \text { Mas ¿qué pincel tan primo aurá bastante, } \\
& \text { a retratar los pródigos frutescos...? }
\end{aligned}
$$

Ante tanta belleza no cabe más que "apoderarse" de la belleza, lanzarse al disfrute de tanta preciosa maravilla, tal como hace la musa del poeta:

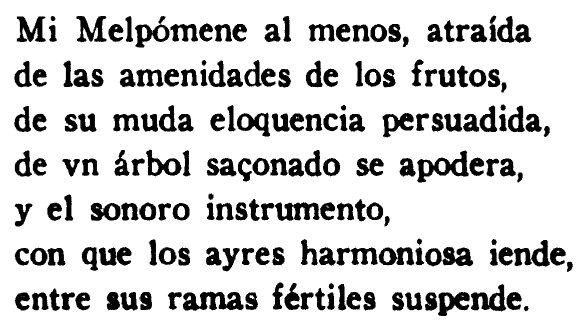

(vv. 303-309) 
Los frutos poseen una muda elocuencia que convence a quien los mira. El mundo nos habla a través de sus elementos y nos invita al goce. Aquí es donde reside la similitud de la Selva con el collige, virgo, rosas de Ausonio.

Góngora es el poeta de los sentidos, sus seguidores lo aprendieron muy bien y se lanzaron a pintar cuadros de frenética belleza en soledad.

Góngora toma como punto de partida la Naturaleza. Aunque llegue en la creación metafórica e hiperbólica a la visión exaltada de la realidad, potencializando sus rasgos hasta lo incomparable y encadenando las metáforas hasta formar como planos de otra realidad superpuesta al objeto que se describe, sin embargo, siempre se arranca del plano real de lo natural. Aunque se le interponga al mirar la naturaleza todo un mundo de recuerdos de figuras y mitos que se unen o esconden tras los árboles, plantas o flores, siempre queda la actitud de situarse frente a esa naturaleza en su visión más libre y amplia, falta de elementos artificiales (Orozco [1974], pág. 129).

Exaltación, pues, de luces, colores y sonidos; exaltación hiperbólica, también de formas, todo apretándose y recargándose; y exaltación de los íntimos impulsos de esa naturaleza humanizada, que presta a la visión un intenso, aunque contenido dinamismo; todo, en suma, de perfecta equivalencia con el cuadro de paisaje del Barroco ([1984] pág. 63).

Esto es lo que habia que aprender, lo que había que imitar. Unas veces, la imitación llega hasta tal punto de perfección que ni el propio Góngora renunciaría a recoger como propios algunos de los versos que Ginovés incluye en este poema, pero, por lo general, falta una mayor universalización de los elementos de la naturaleza, una desautomatización de los esquemas ya prefijados y una abstracción del concepto de belleza. La descripción inmediata es un gran acierto en Ginovés, pero entraña la misma limitación de su alcance.

\section{Bibliografía}

Alonso, Dámaso (1927), "Góngora y la censura de Pedro de Valencia", en Revista de Filología Española, XIV, págs. 347-368.

- - (1982), (ed.), Luis de Góngora, Soledades, Madrid, Alianza Editorial (Primera ed. en 1927).

Beverley, J. (1980), (ed.), Luis de Góngora, Soledades, Madrid, Cátedra.

Blecua, José Manuel (1945), (ed.), Cancionero de 1628. Edición y estudio del Cancionero 250-2 de la Biblioteca Universitaria de Zaragoza, Madrid, C.S.I.C. (Incluye la edición de la Selva al verano de Ginovés).

Cascardi, Anthony J. (1980), "The Exit from Arcadia: Reevaluation of the Pastoral in Virgil, Garcilaso and Góngora", en Journal of Hispanic Philology, IV, págs. 119141. 
Curtius, Ernst Robert (1981), Literatura europea y Edad Media latina, Madrid, F.C.E. (Primera ed. en alemán en 1948).

Egido, Aurora (1978), "La poesía descriptiva en Aragón", en su edición de Miguel Discastillo, Aula de Dios, Zaragoza, Libros Pórtico.

(1979), La pocsía aragonesa del siglo XVII (Raices culteranas), Zaragoza, Institución "Fernando el Católico".

- (1981), (ed.), Pedro Soto de Rojas, Paraiso cerrado para muchos, jardines abiertos para pocos. Los fragmentos del Adonis, Madrid, Cátedra.

Ginovés, Matías. Vide Blecca (1945).

Góngora, Luis de. Vide Alonso (1982).

. Vide Betertey (1980).

. Vide MiLLÉ (1972).

Jammes, Robert (1983), "Elementos burlescos en las Soledades de Góngora", en Edad de Oro, II, págs. 99-112.

Martínez Ruiz, José (1912), "Garcilaso y Góngora", en Lecturas españolas, Madrid, Espasa-Calpe, págs. 57-63.

Millé y Giménez, Juan e Isabel (1972), (ed.), Luis de Góngora, Obras Completas, Madrid, Aguilar. (Primera ed. en 1933. Citado M).

Molmo, Maurice (1978), "Semántica y poética", en Semántica y poética (Góngora y' Quevedo), Barcelona, Crítica. (Primera ed. en francés en 1959).

Nisbet, R. G. M. y Hubbard (1970), A Commentary on Horace Odes, Oxford, Oxford at the Clarendon Press.

Orozco Dínz, Emilio (1974), "Introducción a un poema barroco granadino (De las Soledades gongorinas al Paraiso de Soto de Rojas)", en Paisaje y sentimiento de la naturaleza en la poesía española, Madrid, Ediciones del Centro. (Primera ed. en 1955).

(1984), Introducción a Góngora, Barcelona, Crítica.

Poggioli, Renato (1975), The Oaten Flute, Cambridge Mass., Harvard University Press. Rico, Francisco (1970), El pequeño mundo del hombre. Varia fortuna de una idea en las letras españolas, Madrid, Castalia.

Sánchez Robayna, Andrés (1983), Tres estudios sobre Góngora, Barcelona, Llibres del Mall.

White, Evelyn (1968), (ed.), Ausonius's poetry, Harvard, University Press. 